\title{
ワークショップ12 资症と活性酸素・NO
}

\author{
座長 吉川 敏一（京都府立医科大学・第一内科） \\ 末松誠（慶應義塾大学・医学部・医化学） \\ 座長のことば
}

高濃度の分子状酸素や活性酸素の過剩生成に対する暴露は酸素ストレスとして知られている。 生体は ROS を微生物の侵入に対する防御機構として積極的に利用する一方で、ROS の細胞毒性が 原因で起こる病態が炎症性疾患、血管病、神経変性疾患をはじめとして数多く知られている。高等 生物の持つミトコンドリアをはじめとする酸素呼吸を利用した高エネルギー獲得システムは、低酸 素暴露ののちに急激な酸素供給を受けると逆説的な機能破綻を呈する。この現象は Oxygen Paradox と呼ばれ、虚血再潅流障害の主因として多くの研究者がメカニズムの解明に取り組んできた。この ような酸素ストレスに関する研究は ROSやNO の保持する生体構成成分との高い反応性に起因する 毒性作用とこれに対する宿主の防衛機構という二元論的パラダイムから展開されてきた。しかしな がら近年、神経細胞、血管内皮細胞、血管平滑筋細胞、繊維芽細胞などの食食能のない細胞が、細 胞外シグナルに反応して、比較的少量の ROS が生成され細胞機能を調節することが示唆されるよう になり、ROS を遺伝子発現、蛋白の転写後修飾の調節に関与する生理的 messenger 分子として考え る概念が構築されつつある。本ワークショップでは ROS と NO、CO などのガス分子の相互作用で 起こる炎症反応の修飾メカニズムについての最近の知見をもとに討論したい。

W12-1 Heme oxygenase による酸素ストレスと炎症反応の制御機構

末松 誠、牧野 信也、石村 巽

慶應義塾大学医学部医化学

Heme oxygenase (HO) は protoheme-IX を酸素添加反応により分解し還元鉄、CO、biliverdin を 生成する酵素である。演者らは、CO が肝蔵の血管抵抗を低く保つための内因性弛緩物質であるこ とを見い出す一方、 biliverdin や bilirubin が自殺型抗酸化物質として活性酸素を消去し、誘導型 HO (HO-1)の発現に伴い炎症反応を抑制することを明らかにした。HO-1 は本来 heat shock protein である ことを考虑すると、䤃素反応の生成物に依存した生物活性とともに、誘導された蛋白そのものに酵 素活性に依存しない生物活性が存在する可能性がある。この可能性を検討する目的で、HO-1 の基質 である protoheme-IX が蛋白に結合するために必須のアミノ酸である Histidine を Alanine に置き換え た変異 cDNA を作成し (H25A) これを種々の細胞に発現させ wild-type cDNA の発現株との phenotype の比較検討を行った。ヒト単球系細胞株 U937 では wild-type HO-1cDNA の高発現株で Integrin を介 した細胞接着が著明に低下し、この現象は H25A mutant では認めなかったことから、HO-1 の酵素活 性に依存した生物作用であることが示唆された。一方ラット肥満細胞株 RBL2H3 を用いた脱顆粒反 応性の実験系では wild type, H25A mutant がともに膜刺激に対する感受性が低下した。これらの結果 から HO-1 には従来まで知られていなかった抗炎症性生物作用があることが示唆された。 
W12-2 炎症性腸疾患における炎症性サイトカインならびに誘導型一酸化窒素合成酵素の 発現とphenyl N-tert-butylnitrone（PBN）の効果に関する検討

$\bigcirc$ 内藤裕二、高木智久、松山希一、八木信明、吉田憲正、吉川敏一、 近藤元治、Yashige Kotake ${ }^{1)}$ 京都府立医科大学第 1 内科、

2) Oklahoma Medical Research Foundation

[目的］実験的dextran sodium sulfate（DSS）腸炎モデルを用いて，炎症性サイトカインな らびに誘導型一酸化窒素合成酵素の発現、 NF- $\kappa$ B活性化の関与を検討し、NF- $\kappa \mathrm{B}$ を標的とし た治療の可能性を検討した。 [方法] 6週齢雌性BALB/cマウスを用いて，8\%DSSの自由飲水 により炎症性腸疾患モデルを作製した。経時的に，体重，腸管長，腸管内出血，組織TNF $\alpha$, 好中球浸潤としてmyeloperoxidase(MPO)活性, TNF $\alpha$ mRNA, iNOSmRNA発現, EMSAに よるNF-kB活性化の検討を行った. フリーラジカル捕捉作用を有する phenyl N-tert-' butylnitrone（PBN）の有効性についても検討した。［結果］1）DSS腸炎では経時的に大腸 粘膜層中心に著明な炎症細胞浸潤を伴う腸炎が発生し、PBNの投与は濃度依存性にそれらを抑 制した. 2) DSS腸炎組織ではNF- $\kappa$ B活性化, TNF $\alpha$ mRNA, iNOSmRNA発現増強, TNF $\alpha$ 蛋白，MPO活性の増強がみられ、PBNはそれらを有意に抑制した．［結論］DSS 腸炎におけ るNF- $\kappa$ Bの活性化、炎症性サイトカインやiNOS遺伝子の発現六進を確認した. PBNによる粘 膜傷害抑制効果にNF- $\kappa$ B活性化の抑制が関与することが示唆された.

\title{
W12-3 炎症局所での好中球の活性酸素代謝とシグナル伝達
}

\author{
○佐藤英介、内海耕慥 *、井上正康
}

\section{大阪市立大学医学部生化学教室、 *倉敷成人病センター}

腫瘍壊死因子（TNF- $\alpha$ ) や顆粒球コロニー刺激因子（G-CSF）等によるヒト末梢血好中球のプ ライミングには、チロシンキナーゼの活性化と数種の蛋白質のチロシンリン酸化が関与する。ウ エスタンブロッテングと免疫沈降法による解析の結果、ヒト末梢血好中球にはLyn, Syk, Fgr, Hck, Btkの5種のチロシンリン酸化酵素が存在し、TNF- $\alpha$ にっってLyn とSykキナーゼが著明に活性化 されることが判明した。また、プライミングによるスーパーオキシド産生およびチロシンリン酸 化がSykキナーゼ阻害剤 piceatannolにより抑制されることより、Sykキナーゼの関与が強いことが 示唆された。この際、プライミングと平衡して $115 \mathrm{kDa}$ 蛋白質がリン酸化されることから、本反応 がプライミングに関与する可能性が考えられる。プライミングはJAK2 キナーゼ阻害剂AG490に よって全く抑制されない。プロトオンコジーンc-Cblの抗体を用いた免疫沈降解析により、 $115 \mathrm{kDa}$ 蛋白質の一部はc-Cblであることが判明した。好中球様に分化したHL-60細胞を用いてTNF$\alpha$ 依存性プライミング反応におけるチロシンキナーゼの関与を解析した結果、末梢血好中球と同 様に、srcキナーゼと $115 \mathrm{kDa}$ 蛋白質のリン酸化と同時にスーパーオキシドが産生されることが判 明した。c-Cblのアンチセンスを用いた解析により、本プライミングの一部にc-Cbが関与する可与 能性が示唆された。以上の所見と症局所の好中球を用いた解析結果より、炎症局所での好中球活 性酸素化機構におけるシグナル伝達と活性酸素代謝の様相について考察する。 
W12-4 感染症と活性酸素・NO

赤池孝章

熊本大・医・微生物学

感染防御反応の一環として産生される活性酸素や一酸化窒素 (NO)は、宿主の主要な防御 因子であるだけでなく、炎症のメディエーターとして機能し、時に生体に酸化ストレスを もたらし、感染病態を增悪させる。この様な活性酸素やNO の二面的な活性は、宿主と病 原体の微妙な相互作用により発現される。

我々はこれまで、様々なウイルスおよび細菌感染モデルを用いて、感染病態における 活性酸素・NO の役割を解析してきた。その結果、例えばサルモネラ感染などにおいて活 性酸素・NO は、重要な感染防御作用を発揮するが、インフルエンザウイルス、センダイ

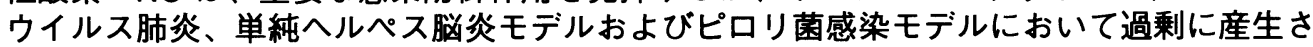
れる活性酸素・NO およびそれら由来のパーオキシナトライトは、内因性の病原因子とし て作用し組織損傷をもたらすことが示唆された。さらに、パーオキシナトライトをはじめ とするNO由来の反応性窒素酸化物が、感染病巣において強い変異原性を発揮し病原体の 遗伝子変異を促進したり、炎症性発癌の大きな要因となることがわかってきた。そこで本 ワークショップにおいては、感染症における活性酸素・NO のユニークな病態生理につい て、国内外の最新の知見を紹介する。 